\title{
The myth that farmers are well fed, and the reality of food insecurity among Vermont's agricultural laborers
}

\author{
Review by Emily Reno, University of Minnesota*
}

Review of Life on the Other Border: Farmworkers and Food Justice in Vermont, by Teresa M. Mares. (2019). Oakland: University of California Press. Available as hardcover, paperback, and ebook; 240 pages. Publisher's website:

https://www.ucpress.edu/book/9780520295735/life-on-theother-border

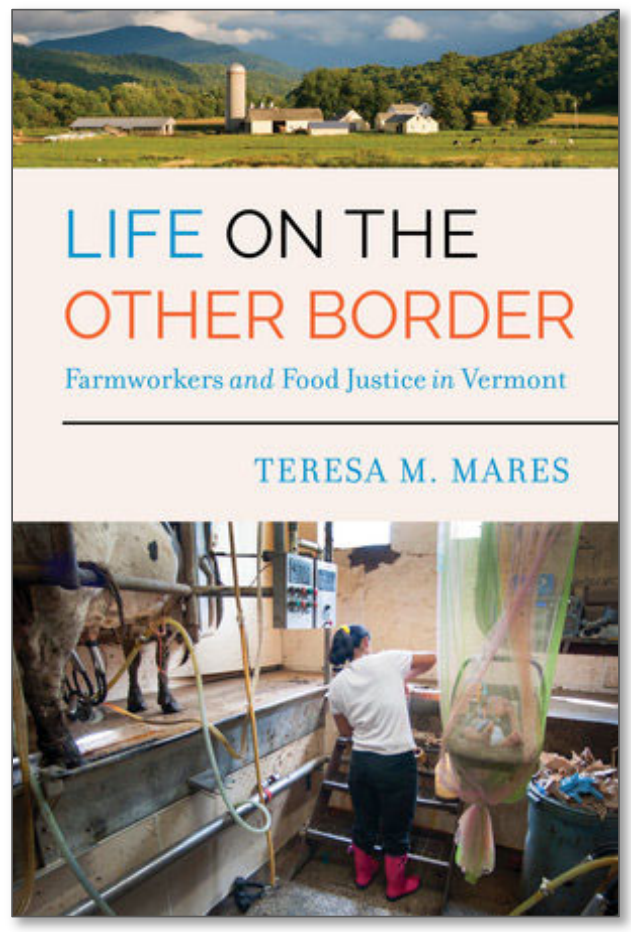

Submitted February 3, 2020 / Published online May 7, 2020

Citation: Reno, E. (2020). The myth that farmers are well fed, and the reality of food insecurity among Vermont's agricultural laborers [Book review]. Journal of Agriculture, Food Systems, and Community Development, 9(3), 331-332. https://doi.org/10.5304/jafscd.2020.093.025

Copyright (C) 2020 by the Author. Published by the Lyson Center for Civic Agriculture and Food Systems. Open access under CC-BY license.

$\mathrm{B}$ ased on six years of community-based ethnographic research, Teresa M. Mares' Life on the Other Border: Farmworkers and Food Justice in Vermont takes readers on a journey of understanding the facets of food security, from its theoretical underpinnings to its felt experiences from agricultural

* Emily Reno is a Humphrey Fellow at the University of Minnesota in the Urban and Regional Planning Program. With a tender heart and bold aspirations, Emily Reno is on the path to building a network of changemakers who solder the arts, health and wellness, and agricultural systems into tools for narrative disruption and economic vitality in rural communities. She is fiercely committed to sowing fertile grounds for social equity and environmental justice by stitching together a social fabric that values complex identity, storytelling, and personal growth. She can be contacted at emilyp.reno@gmail.com. laborers in the dairy industry. This book uses several different entry points into the complex issue of border (in)security and the implications of the current national sentiments toward undocumented immigrants. Mares' research reinforces the notion that standardized measurements are insufficient to tell the story, and that there is always more than meets the eye when it comes to the bucolic images of Vermont and its revered agricultural industry. This book illustrates the importance of entering places where food insecurity is felt and of getting close to the people whose problems we want to solve in order to be effective.

Chapter 1 outlines the theoretical frameworks that influenced Mares' research and teases apart what 'border' actually means and how it manifests, 
whether at the border around the farm in question, around the private home, or between Canada and Mexico. Grounding readers in the understanding that the northern border (in contrast to the south) can be just as hostile toward migrants, Mares prepares readers to dig deeper into how both physical and regulatory structures are "porous to the movement of capital and impervious to the movement of people" (p. 33). It soon becomes clear that readers should not expect a feel-good kind of book; rather, they should expect to be challenged to reimagine the ways we institutionalize the assessment of someone's food security.

Chapter 2 moves into a deeper exploration of household food security practices among Latinx dairy workers in Vermont by evaluating the Household Food Security Survey Model (HFSSM) and how, despite being marked as 'food secure' by this tool, many workers disproportionately experience food insecurity. In some cases, Mares writes, "food insecurity among farmworkers is as high as three to four times the national average" (p. 60). This fact, as well as other statistical data used to support Mares' arguments, reveals the shockingly poor working conditions in which farm laborers in Vermont-and most likely elsewhere in the country-must operate.

Chapter 3 describes the potential for food sovereignty for Vermont's farmworkers who participate in Huertas, a kitchen gardening project that allows farm laborers to garden near their places of residence. Mares uses this space to make a case for why food sovereignty can and should operate both as an all-encompassing movement to rebuild locally controlled food systems, and as a set of everyday practices and food choices (p. 88). This chapter helps readers understand how gardens serve as a tool for immigrants to protect their cultural and culinary heritage, despite xenophobia and pressures to assimilate (p. 93).

Chapter 4 uses Mares' ethnographic fieldwork and interviews with stakeholders to elaborate on the challenge service providers face in providing goods and services under surveillance for undocumented farmworkers. These service providers, including state and federal agencies, communitybased organizations, and individuals, must maintain high visibility for funders, employers, and larger agencies while obscuring the presence of undocumented farmworkers (p. 26). Mares explains how Vermont's farmworkers have limited mobility, and that service providers and informal networks are vital to creating access to outside environments and culturally appropriate foods that might otherwise be unobtainable.

Lastly, Chapter 5 turns the reader's attention to farmworker-led organizing efforts spearheaded by Migrant Justice, and the successes they have had in advocating for better working conditions. Mares situates the content of this chapter in light of a broader call for an overhaul of our food system to dismantle the corporate food regime (p. 148). This chapter is helpful for readers who seek to understand how successful grassroots organizing takes place, as well as how research and activism can overlap.

Life on the Other Border would be an excellent book for anyone who works in border security, agricultural labor advocacy, and/or legal protections for immigrants, because it illustrates that while we can spend years debating the theoretical frameworks that guide our understanding of the food system, at the heart of it all are people. Humans rights, dignity, and justice are in the crucible of this issue, and anyone who reads this book-regardless of their ability follow the more academic language-will find themselves wondering how our legal systems can tolerate such treatment of workers. That being said, Mares could make her research more accessible by transforming it into a reference tool for stakeholders in this field (such as SNAP-Ed educators, employees of nonprofit organizations serving underrepresented populations, and rural economic development professionals). This could include main takeaways or lessons learned as bullet points or a summary table focusing on a specific policy and its outcome. Mares' goal in writing this book was to "highlight how resiliency is found in the food-related activism and daily practices of Vermont's migrant dairy workers" (p. 37). She successfully conveys the importance and value that agricultural laborers bring to our food system, and how their identities are often erased from the consumer experience further down the value chain. 